\title{
Effectiveness of Hot Aerosol Extinguishing Agent in Suppressing Oil Fires at Different Locations
}

DOI: $10.15255 /$ KUI.2016.035 KUI-43/2016

Professional paper Received August 30, 2016 Accepted October 19, 2016

\author{
W.-F. Zheng, ${ }^{a^{*}}$ A. -H. Liu, ${ }^{\text {a L. Zhang, }}{ }^{\text {b }}$ \\ Q. -W. Li, ${ }^{a}$ X.-Y. Lin ${ }^{a}$ and R.-M. Pan ${ }^{a}$ \\ a School of Chemical Engineering, Nanjing University of Science and Technology, \\ Nanjing 210 094, P.R. China \\ bShanghai Fire Research Institute of MPS, Shanghai 200 438, P.R. China
}

\begin{abstract}
$\|$ Abstract
As a suitable candidate for the next halon alternative gaseous fire-extinguishing agent, it is very meaningful to investigate how to improve the fire-extinguishing capacity of hot aerosol fire extinguishing agents for local fires. When fire breaks out, the actual fire location is unpredictable, and the extinguishing efficiency of hot aerosol extinguishing agent will be observably affected by the fire locations due to different flame patterns and intensities at different fire locations. In this work, the use of the hot aerosol extinguishing agent in suppressing oil fires at different locations, including open, partially open, and fully closed locations, has been investigated in order to obtain the regularity of the effectiveness of the hot aerosol extinguishing agent in suppressing a local fire. The results have shown that the hot aerosol extinguishing agent is more effective in suppressing an oil fire in a fully closed system than in an open system or partially open system. The shortest fire-extinguishing time was for the fire in the corner, followed by the one in the middle, and the fire against the wall took the longest time to extinguish for fire locations in a partially open system and a fully closed system, respectively. In addition, the fire extinguishing process involves varying degrees of flame enhancements.
\end{abstract}

$\|$ Keywords

Hot aerosol fire extinguishing agent, local fire, oil fire, fire extinguishing time, fire location

\section{Introduction}

Hot aerosol fire extinguishing agents have good efficiency in fire extinguishing, low ODP and GWP value, and they do not need to be stored in a pressurized container since they do not need to be driven out by pressurized inert gases. ${ }^{1-5}$ Therefore, research and development of such new fire suppression technology have been given much attention, especially in developed countries. ${ }^{1,3}$ In order to be effective in extinguishing fire and preventing re-ignition after extinguishment, an effective way to release hot aerosol fire extinguishing agents is very important. ${ }^{3,6}$ While suppressing fire at different locations, there are significant differences in the extinguishing efficiency of hot aerosol fire extinguishing agents due to the distinct difference in flame intensity, flame height, smoke movement, and the diffusion of the extinguishing agent in the flame zone. ${ }^{6,7}$

A lot of research work has been carried out on hot aerosol fire extinguishing agents, but the emphasis is on formulation optimization, burning behaviour, and how to improve the fire-extinguishing capacity of the agents. Wang et al. investigated the diffusivity-performance relation of the HEAE aerosol extinguishing agent, and found a high concentration of extinguishing particles near the ceiling. ${ }^{8} \mathrm{Ma}$ et al. designed some formulations composed of potassium nitrate, strontium nitrate and sucrose, and then the influence of strontium nitrate content on the hot aerosol

${ }^{*}$ Corresponding author: Wenfang Zheng, Ph.D e-mail: zwf198181@163.com fire-extinguishing agent was researched. ${ }^{9}$ The combustion mechanism of fire-extinguishing propellants based on potassium nitrate was investigated by Denisjuk et al. ${ }^{10}$ Kyungok et al. ${ }^{2}$ studied the extinction effectiveness of hot aerosol extinguishing system with the main component of potassium nitrate. Zhu et al. ${ }^{11}$ investigated how to reduce the combustion temperature of hot aerosol fire extinguishing agent. However, there are few studies on the use of hot aerosol extinguishing agent for suppressing local fires at different locations. When fire breaks out, the actual fire location is unpredictable, and the extinguishing efficiency of hot aerosol extinguishing agent will be observably affected by fire locations due to the difference in flame patterns and intensities at different fire locations.

In this study, the use of hot aerosol extinguishing agent for suppressing oil fires at different locations, including open, partially open, and fully closed locations, is explored to obtain the regularity of its suppressing efficiency, especially for application of the agent in local fires.

\section{Experimental}

\subsection{Samples}

Hot aerosol extinguishing agent is made from potassium nitrate, dicyandiamide, and phenol formaldehyde resin after refining, mixing, forming, coating, and drying. The main properties of the extinguishing agent are presented in Table 1. 
Table 1 - Properties of Hot Aerosol Extinguishing Agent Tablica 1 - Svojstva sredstva za gašenje vrućim aerosolom

\begin{tabular}{l|c}
$\begin{array}{l}\text { diameter } \\
\text { promjer }\end{array}$ & $34 \mathrm{~mm}$ \\
$\begin{array}{l}\text { height } \\
\text { visina }\end{array}$ & $33 \mathrm{~mm}$ \\
$\begin{array}{l}\text { density } \\
\text { gustoća } \\
\text { burning rate } \\
\text { brzina gorenja }\end{array}$ & $1.67 \mathrm{~g} \mathrm{~cm}^{-3}$ \\
\end{tabular}

\subsection{Local fire extinguishing experiments}

\subsubsection{Fire extinguishing system}

The experiments were conducted in three different systems as follows: (1) Open system - an open environment without obstructions within a $5 \mathrm{~m}$ radius and a wind speed lower than $0.2 \mathrm{~m} \mathrm{~s}^{-1}$; (2) Partially open system a rectangular space surrounded by walls on three sides, $L \times H=180 \mathrm{~cm} \times 240 \mathrm{~cm}$ and wind speed lower than $0.2 \mathrm{~m} \mathrm{~s}^{-1}$; and (3) Fully closed system - a single chamber with $L \times W \times H=100 \mathrm{~cm} \times 100 \mathrm{~cm} \times 100 \mathrm{~cm}$.

\subsubsection{Local fire extinguishing test}

The local fire extinguishing tests were conducted in the above three systems respectively. The apparatus shown in Figs. 1 and 2, includes fire extinguishing bar, fuse and oil pan $(L \times W \times H=20 \mathrm{~cm} \times 20 \mathrm{~cm} \times 10 \mathrm{~cm})$. The fire extinguishing bar was fixed to a ring stand when tested. The fire extinguishing bar, used for discharging the hot aerosol extinguishing agent, was made up of two parts: a cylindrical steel cartridge case with a nozzle used for placing the cylindrical grain, and a cylindrical handle. The fire extinguishing bar was pre-charged with a $50 \mathrm{~g}$ hot aerosol extinguishing agent. The diameter of the nozzle was $10 \mathrm{~mm}$. As shown in Fig. 1, the angle between the fire extinguishing bar and the ring stand is $\angle A=45^{\circ}$. The distance between the nozzle and the top of the oil pan is $L=50 \mathrm{~cm}$. Before each

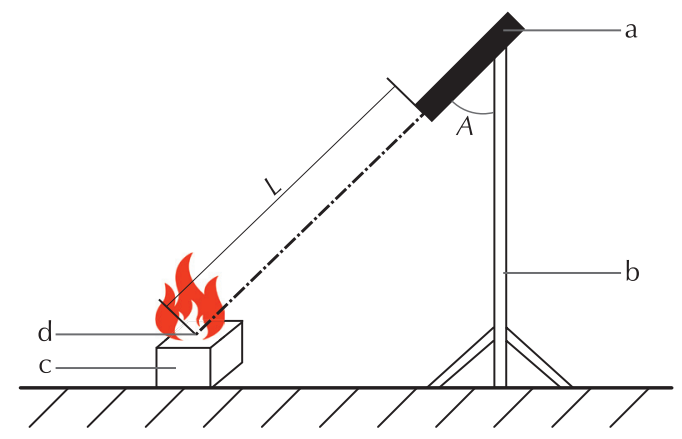

Fig. 1 - Schematic diagram of the extinguisher $\mathrm{a}$ - fire-extinguishing bar, $\mathrm{b}$ - ring stand, $\mathrm{c}$ - oil pan, $\mathrm{d}$ centre of the oil pan

Slika 1 - Shema aparata za gašenje požara a - cijev aparata za gašenje požara, b - stativ, c - posuda $\mathrm{s}$ benzinom, $\mathrm{d}$ - centar posude s benzinom test, a $50 \mathrm{~mm}$ water cushion was poured on the bottom of the oil pool, followed by addition of $10 \mathrm{~mm}$ of No. 93 gasoline into the oil pan. After all the conditions had been prepared, the gasoline was ignited. For the gasoline pool fire, $30 \mathrm{~s}$ of pre-burning was allowed to reach steady burning conditions. The agent was then ignited through a fuse. It is considered to be successful if the flame does no rekindle within $1 \mathrm{~min}$ after extinguishing and the gasoline can be ignited again. The entire extinguishing process was shot using a lens, and the flame extinction time recorded. The flame extinction time was calculated from the time the extinguishing agent began to disperse until flame extinction.

\section{Results and discussion}

\subsection{Hot aerosol extinguishing agent suppressing an oil fire in open system}

After the hot aerosol extinguishing agent is ignited, the extinguishing aerosol produced and driven by the gas combustion products is dispersed to the desired flame zone. Fig. 3 shows the aerosol extinguishing agent suppressing an oil fire in an open system. As illustrated in Fig. 3, the aerosol extinguishing agent reaches the flame zone after $4.0 \mathrm{~s}$ pre-dispersing, and thereafter the flame becomes brighter with the volume and flame height significantly increasing. With the growing concentration of the aerosol extinguishing agent, the suppression effect of the extinguishing agent becomes strong, the flame gradually dims, the flame height and volume become small, and the flame completely goes out after $7.1 \mathrm{~s}$.

\subsection{Hot aerosol extinguishing agent suppressing an oil fire in partially open system}

Oil fire in a partially open system can locally increase the concentration of gasoline in air because of the shielding effect of the wall, thus possibly resulting in an increase in flame intensity. This has a negative effect on fire suppression. ${ }^{6} \mathrm{~A}$ partially open system can also lead to differences in the diffusion of the hot aerosol extinguishing agent, thereby affecting the concentration of the extinguishing agent in the flame zone and the extinguishing efficiency. In this

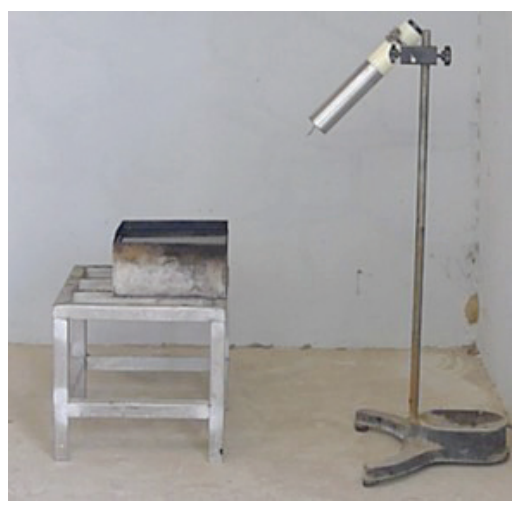

Fig. 2 - Photo of the extinguisher

Slika 2 - Fotografija aparata za gašenje požara 


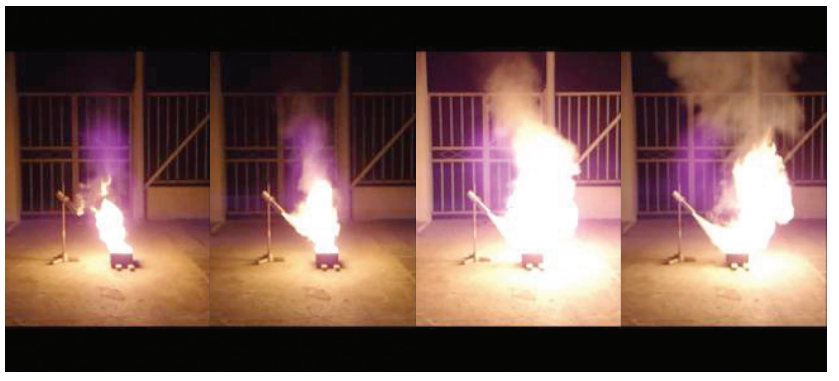

$0.3 \mathrm{~s}$

$4.0 \mathrm{~s}$

$5.2 \mathrm{~s}$

$5.8 \mathrm{~s}$

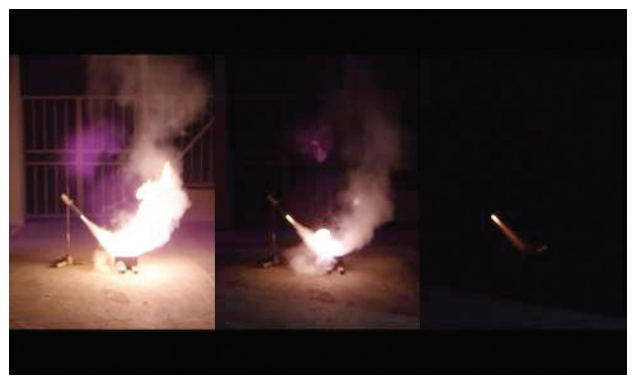

$6.4 \mathrm{~s}$

$6.9 \mathrm{~s}$

$7.1 \mathrm{~s}$

Fig. 3 - Hot aerosol extinguishing agent suppressing an oil fire in open system

Slika 3 - Gašenje upaljenog benzina na otvorenom prostoru sredstvom za gašenje vrućim aerosolom

part, three typical fire locations were considered, including oil fire in the middle, oil fire against the wall, and oil fire in the corner of the partially open space, respectively.

\subsubsection{Hot aerosol extinguishing agent suppressing an oil fire in the middle of a partially open space}

Fig. 4 shows the aerosol extinguishing agent suppressing an oil pool fire in the middle of the partially open system. As shown in Fig. 4, the extinguishing agent reached the flame zone after $4.1 \mathrm{~s}$ pre-dispersing, and thereafter flame enhancements appeared as the flame became brighter, and the flame height and volume grew larger than before. With an increasingly higher concentration of the aerosol extinguishing agent, the flame gradually dims and the flame volume becomes smaller until it completely goes out after

$7.4 \mathrm{~s}$.

\subsubsection{Hot aerosol extinguishing agent suppressing an oil fire against the wall of a partially open space}

Fig. 5 presents the hot aerosol extinguishing agent suppressing an oil fire against a wall. The results in Fig. 5 show that the extinguishing agent reaches the flame zone after $4.2 \mathrm{~s}$ pre-dispersing. Under the action of a force perpendicular to the wall, a part of the extinguishing agent falls out of the flame zone, thus making the flame poorly restrained. In addition, because of the shielding effect of the wall, the concentration of gasoline in the air also locally increases, with more serious flame enhancements compared with the case in the middle. The flame height is significantly increased, the flame becomes brighter, and the flame

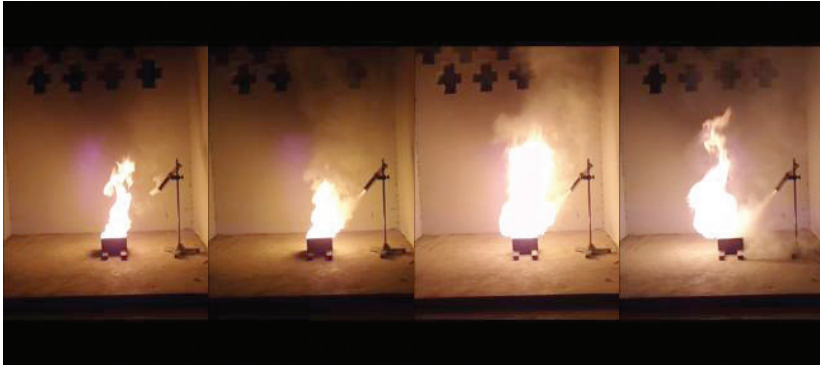
$0.3 \mathrm{~s}$
$4.1 \mathrm{~s}$
$5.0 \mathrm{~s}$
$6.4 \mathrm{~s}$

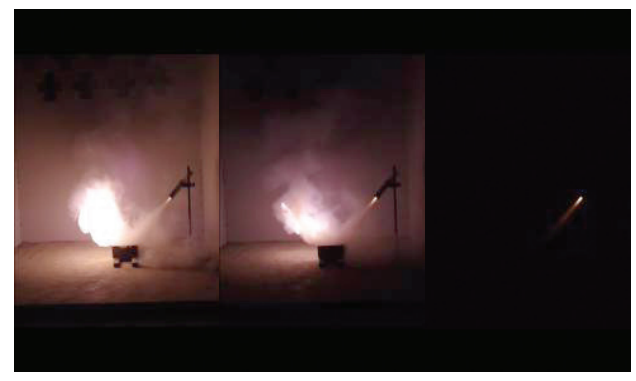

$6.8 \mathrm{~s}$

$7.3 \mathrm{~s}$

$7.4 \mathrm{~s}$

Fig. 4 - Hot aerosol extinguishing agent suppressing an oil fire in the middle of partially open space

Slika 4 - Gašenje upaljenog benzina u središtu djelomično otvorenog prostora sredstvom za gašenje vrućim aerosolom

volume becomes larger. After a relatively long period of flame enhancements with a gradual increase in the concentration of the aerosol extinguishing agent, the flame is slowly dimmed, and the flame volume gradually becomes smaller until it completely goes out after $9.0 \mathrm{~s}$. The flame extinction time is also longer than that in the case in the middle.

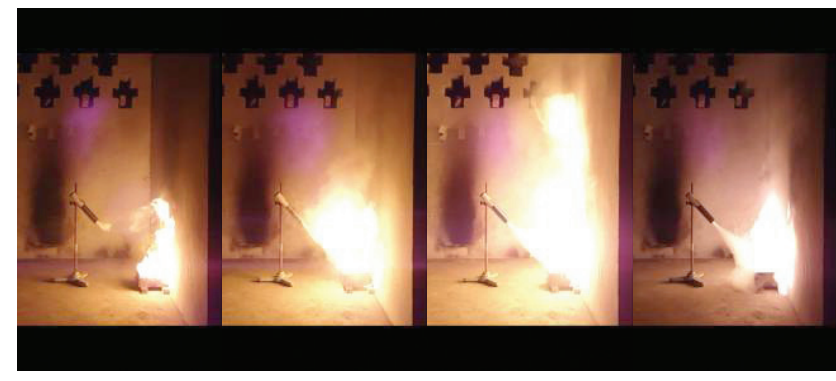

$0.2 \mathrm{~s}$

$4.2 \mathrm{~s}$

$6.1 \mathrm{~s}$

$7.5 \mathrm{~s}$

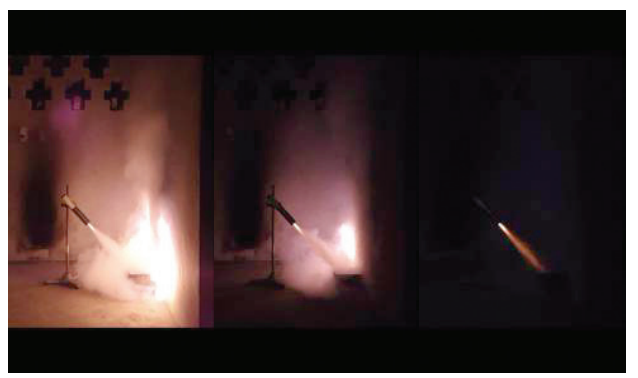

$8.5 \mathrm{~s}$

$8.8 \mathrm{~s}$

$9.0 \mathrm{~s}$

Fig. 5 - Hot aerosol extinguishing agent suppressing an oil fire against the wall

Slika 5 - Gašenje upaljenog benzina uza zid sredstvom za gašenje vrućim aerosolom 


\subsubsection{Hot aerosol extinguishing agent suppressing} an oil fire in the corner of a partially open space

Fig. 6 shows the hot aerosol extinguishing agent suppressing an oil fire in the corner. It can be observed that the hot aerosol extinguishing agent reaches the flame zone after $4.6 \mathrm{~s}$ pre-dispersing, and thereafter the flame is enhanced to a certain extent. With a gradually increasing concentration of the aerosol extinguishing agent, the flame slowly dims and detaches from the oil surface until it completely goes out after $6.8 \mathrm{~s}$. The flame extinction time is relatively short.

\subsection{Hot aerosol extinguishing agent suppressing an oil fire in a fully closed system}

In a fully closed system, the oxygen supply cannot be obtained sustainably, so the concentration inside the extinguishing chamber may rapidly decline with the burning of gasoline, and the extinguishing particles and fumes produced in the combustion process continue to accumulate. ${ }^{6}$ This may lead to vast differences among the fully closed, open, and partially open systems in the extinguishing efficiency of hot aerosol extinguishing agent. In this part, three typical fire locations were considered also, including oil fire in the middle, oil fire against the wall, and oil fire in the corner of the fully closed space, respectively.

\subsubsection{Hot aerosol extinguishing agent suppressing an oil fire in the middle of a fully closed system}

The hot aerosol extinguishing agent suppressing an oil pool fire in the middle of a fully closed system is shown in Fig. 7.

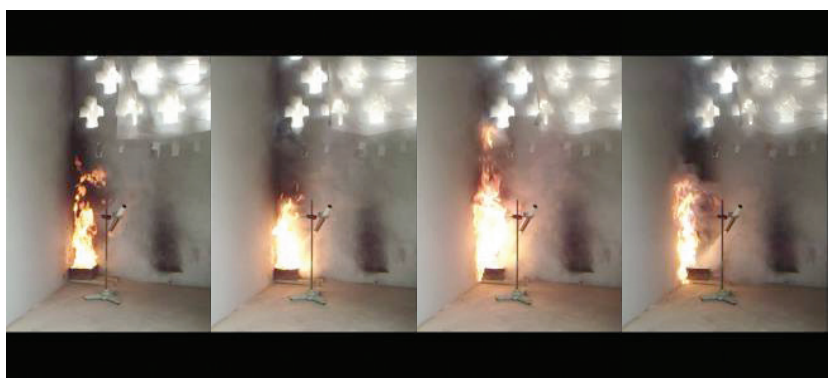

$0.3 \mathrm{~s}$ $4.6 \mathrm{~s}$ $5.1 \mathrm{~s}$ $5.8 \mathrm{~s}$

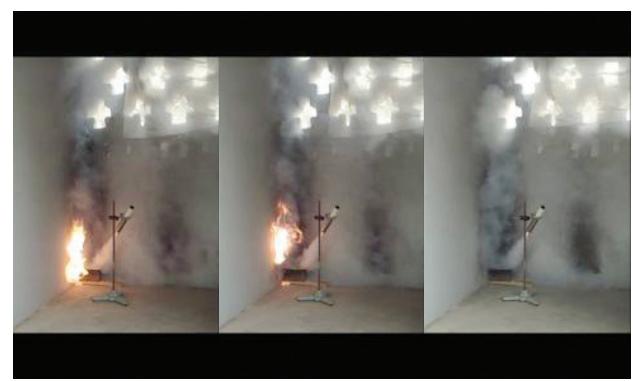

$6.4 \mathrm{~s}$

$6.6 \mathrm{~s}$

$6.8 \mathrm{~s}$

Fig. 6 - Hot aerosol extinguishing agent suppressing an oil fire in the corner

Slika 6 - Gašenje upaljenog benzina u kutu sredstvom za gašenje vrućim aerosolom
The fire source is in the middle of a fully closed space. As shown in Fig. 7, the extinguishing agent reaches the flame zone after $4.2 \mathrm{~s}$ pre-dispersing, and thereafter the flame intensifies. However, in a fully closed system, the flame enhancement time is short, primarily because of the abundance of oxygen consumed in the extinguishing chamber while burning without timely replenishment. With the increasingly high concentration of the extinguishing agent, the flame begins to weaken until it completely goes out after $6.4 \mathrm{~s}$.

\subsubsection{Hot aerosol extinguishing agent suppressing an oil fire against the wall of a fully closed system}

The hot aerosol extinguishing agent suppressing an oil pool fire against the wall of a fully closed space is displayed in Fig. 8. The results in Fig. 8 show that the aerosol extinguishing agent reaches the flame zone after $4.2 \mathrm{~s}$ pre-dispersing, and thereafter the flame enhancements appear. In a fully closed system, the fire source is against the wall and the flame enhancements are intense. An abundance of oxygen is consumed within a short time. Thus, the flame enhancement time is short, and the flame rapidly weakens until it completely goes out after $6.8 \mathrm{~s}$.

\subsubsection{Hot aerosol extinguishing agent suppressing an oil fire in the corner of a fully closed system}

Fig. 9 presents hot aerosol extinguishing agent suppressing an oil pool fire in the corner of a fully closed space. As shown in the figure, the aerosol extinguishing agent reaches the flame zone after $4.0 \mathrm{~s}$ pre-dispersing, and thereafter the flame enhancements appear. In a fully closed system,

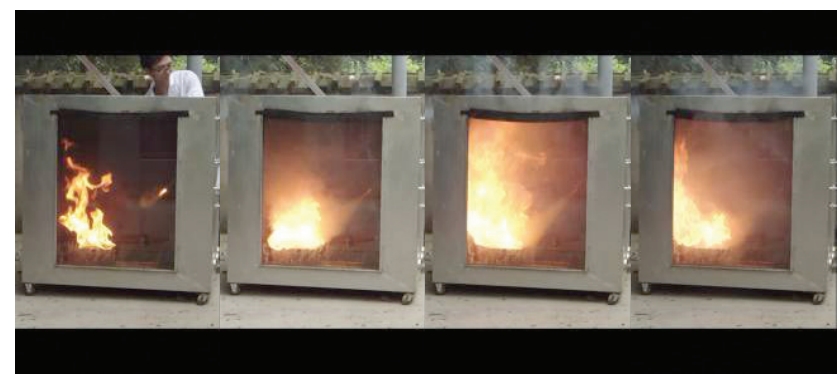
$0.1 \mathrm{~s}$
$4.2 \mathrm{~s}$
$4.6 \mathrm{~s}$
$5.1 \mathrm{~s}$

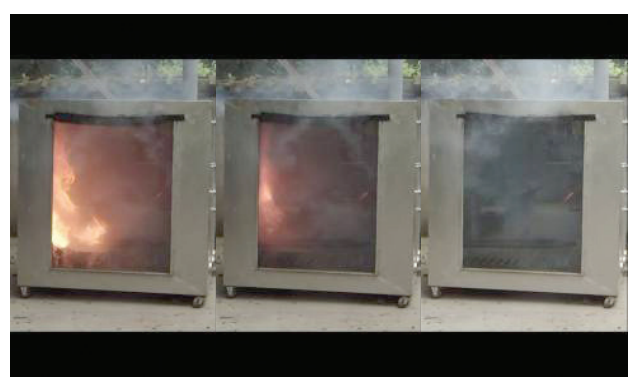

$5.8 \mathrm{~s}$

$6.1 \mathrm{~s}$

$6.4 \mathrm{~s}$

Fig. 7 - Hot aerosol extinguishing agent suppressing an oil fire in the middle of a fully closed space

Slika 7 - Gašenje upaljenog benzina u središtu zatvorenog prostora sredstvom za gašenje vrućim aerosolom 


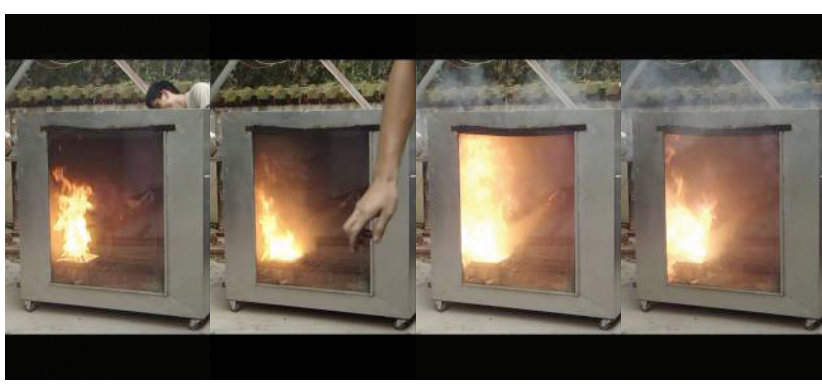

$0.1 \mathrm{~s}$

$4.2 \mathrm{~s}$

$4.9 \mathrm{~s}$

$5.6 s$

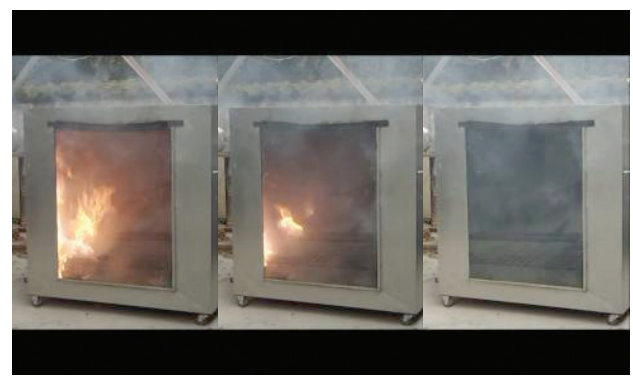

$6.0 \mathrm{~s}$

$6.5 \mathrm{~s}$

$6.8 \mathrm{~s}$

Fig. 8 - Hot aerosol extinguishing agent suppressing an oil fire against the wall of a fully closed space

Slika 8 - Gašenje upaljenog benzina uza zid u zatvorenom prostoru sredstvom za gašenje vrućim aerosolom

when the fire source is in the corner, flame enhancements are not actually serious because of the corner effect. The oxygen consumption is also relatively high. Compared with that in a partially open system, the flame enhancement time slightly decreases, and the flame gradually dims until it completely goes out after $5.9 \mathrm{~s}$.

\subsection{Analysis of the effect of hot aerosol extinguishing agent suppressing an oil fire at different locations}

Table 2 presents the comparison among different systems of the effect of hot aerosol extinguishing agent suppressing oil fires according to the above results and analysis. It can be observed from Table 2 that, overall, the extinguishing time of the fire located in a fully closed system is shorter than the other two fire locations, while the corresponding interaction time of fire located in a fully closed system is shorter than the other two fire locations. This means that hot aerosol extinguishing agent is more efficient in suppressing oil fires in fully closed systems. The reason for this being that the burning of gasoline requires oxygen, but the oxygen supply cannot be maintained sustainably in a fire located in a fully closed system. The concentration of oxygen inside the extinguishing chamber may rapidly decline with the combustion of gasoline, and at the same time, the extinguishing particles and fumes produced in the combustion process continue to accumulate, thus possibly leading to a relatively fast fire extinguishing. ${ }^{6-7}$ Furthermore, it can also be seen from the above results that hot aerosol extinguishing agent can efficiently extinguish oil fire in open, partially open, and fully closed locations. This suggests that hot aerosol extinguishing agent can extinguish a local fire. Therefore, hot aerosol extinguishing agent is a suitable substitute for halon gaseous agents for extinguishing local fires.

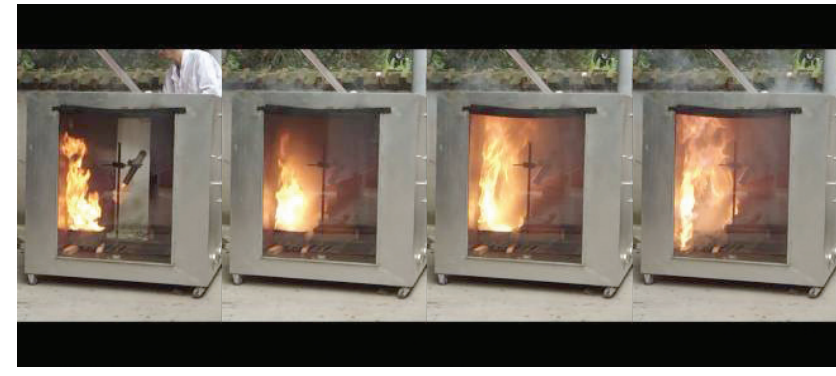
$0.1 \mathrm{~s}$
$4.0 \mathrm{~s}$
$4.4 \mathrm{~s}$
$4.9 \mathrm{~s}$

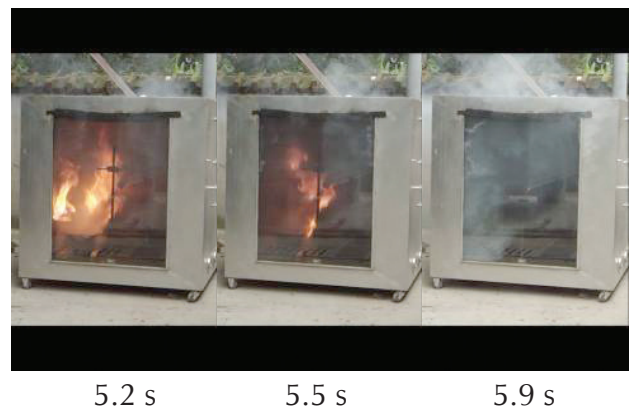

Fig. 9 - Hot aerosol extinguishing agent suppressing an oil fire in the corner of a fully closed space

Slika 9 - Gašenje upaljenog benzina u kutu u zatvorenom prostoru sredstvom za gašenje vrućim aerosolom

Table 2 - Effectiveness of hot aerosol extinguishing agent suppressing an oil fire in different systems

Tablica 2 - Učinkovitost gašenje upaljenog benzina sredstvom za gašenje vrućim aerosolom u različitim sustavima

\begin{tabular}{|c|c|c|c|c|}
\hline \multicolumn{2}{|c|}{$\begin{array}{c}\text { Fire locations } \\
\text { Smještaj plamena }\end{array}$} & $\begin{array}{l}\text { Pre-dispersing } \\
\text { time/s } \\
\text { Vrijeme prije } \\
\text { raspršivanja/s }\end{array}$ & $\begin{array}{c}\text { Extinguishing } \\
\text { time/s } \\
\text { Vrijeme } \\
\text { gašenja/s }\end{array}$ & $\begin{array}{c}\text { Interaction } \\
\text { time /s } \\
\text { Vrijeme } \\
\text { interakcije /s }\end{array}$ \\
\hline \multicolumn{2}{|c|}{$\begin{array}{c}\text { open } \\
\text { na otvorenom }\end{array}$} & 4.0 & 7.1 & 3.1 \\
\hline \multirow{3}{*}{ 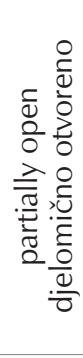 } & $\begin{array}{l}\text { in the } \\
\text { middle } \\
\text { u sredini }\end{array}$ & 4.1 & 7.4 & 3.3 \\
\hline & $\begin{array}{l}\text { against the } \\
\text { wall } \\
\text { uza zid }\end{array}$ & 4.2 & 9.0 & 4.8 \\
\hline & $\begin{array}{l}\text { in the } \\
\text { corner } \\
\text { u kutu }\end{array}$ & 4.6 & 6.8 & 2.2 \\
\hline \multirow{3}{*}{ 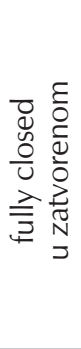 } & $\begin{array}{l}\text { in the } \\
\text { middle } \\
\text { u sredini }\end{array}$ & 4.2 & 6.4 & 2.2 \\
\hline & $\begin{array}{l}\text { against the } \\
\text { wall } \\
\text { uza zid }\end{array}$ & 4.2 & 6.8 & 2.6 \\
\hline & $\begin{array}{l}\text { in the } \\
\text { corner } \\
\text { u kutu }\end{array}$ & 4.0 & 5.9 & 1.9 \\
\hline
\end{tabular}

Note: the interaction time is the time of interaction between the extinguishing agent and the flame. Interaction time equals the extinguishing time minus the pre-dispersing time.

Napomena: vrijeme interakcije je trajanje međudjelovanja sredstva za gašenje i plamena, a jednako je razlici trajanja gašenja i vremena prije raspršivanja. 


\section{Conclusion}

The hot aerosol extinguishing agent can extinguish oil fires in open, partially open, and fully closed locations. When suppressing an oil fire in a fully closed system, hot aerosol extinguishing agent is more effective than in the open system and partially open system, and the fire in the corner is easier to extinguish than that in the middle and against the wall of a fire site. Therefore, as a suitable candidate for the next halon alternative gaseous fire extinguishing agent, the hot aerosol extinguishing agent can be applied to extinguish local fires.

\section{ACKNOWLEDGEMENTS}

The authors would like to acknowledge that this project was supported by the National Natural Science Foundation of China (51306093, 21473130), Fund Project for Key Laboratory of National Defence Science and Technology of China (9140C350309150C35160) and Fundamental Research Funds for the Central Universities (30916011317).

\author{
List of abbreviations and symbols \\ Popis kratica i simbola \\ GWP - global warming potential \\ - potencijal globalnog zatopljenja \\ HEAE - hot aerosol extinguishing agent \\ - sredstvo za gašenje vrućim aerosolom \\ ODP - ozone depletion potential \\ - potencijal razaranja ozona \\ $\angle A \quad$ - angle between the fire extinguishing bar \& the ring stand, ${ }^{\circ}$ \\ - kut između cijevi aparata za gašenje požara i stativa, ${ }^{\circ}$ \\ H - height, $\mathrm{cm}$ \\ - visina, $\mathrm{cm}$ \\ $L \quad$ - length, $\mathrm{cm}$ \\ - duljina, cm \\ W - width, $\mathrm{cm}$ \\ - širina, $\mathrm{cm}$
}

\section{References \\ Literatura}

1. X. T. Zhang, M. H. S. Ismail, F. B. Ahmadun, N. B. H. Abdullah, C. Hee, Hot aerosol fire extinguishing agents and the associated technologies: A review, Braz. J. Chem. Eng. 32 (2015) 707-724, doi: http://dx.doi.org/10.1590/01046632.20150323s00003510.

2. K. Kwon, Y. Kim, Extinction effectiveness of pyrogenic condensed-aerosols extinguishing system, Korean. J. Chem. Eng. 30 (2013) 2254-2258, doi: http://dx.doi.org/10.1007/ s11814-013-0203-8.

3. W. F. Zheng, M. Q, Yan, L. Qin, L. Zhang, D. He, Y. Li, R. M. Pan, Influence of oxidizer on performance of hot aerosol fire-extinguishing agent, J. B. Inst. Technol. 25 (2016) 96-102.

4. P. V. Nikolaev, E. P. Konstantinova, Possibilities for controlling the oxygen balance and composition of fire-extinguishing aerosol generated by epoxy polymer solid fuel elements in means for firefighting, Russ. J. Appl. Chem. 87 (2014) 496499, doi: http://dx.doi.org/10.1134/S1070427214040017X.

5. B. Gerard, B. Michael, F. Eric, B. David, W. Elizabeth, N. Lou, An evaluation of aerosol extinguishing systems for machinery space applications, Fire. Technol. 45 (2009) 43-69, doi: http://dx.doi.org/10.1007/s10694-008-0053-9.

6. X. M. Zhou, G. X. Liao, R. M. Pan, Influence of potassium zitrate on the combustion rate of a water-based aerosol fire extinguishing agent, J. Fire. Sci. 24 (2006) 77-89, doi: http:// dx.doi.org/10.1177/0734904106054711.

7. H. Guo, Technology of hot aerosol fire-extinguishing agent. Vol. 1, Chemical Industry Press, Beijing, 2005.

8. H. Wang, Y. F. Zhang, R. M. Pan, Study on the Diffusion and Fire Extinguishing Performance of HEAE Aerosol Fire Agent, Fire. Sci. Technol. 25 (2006) 474-479.

9. J. Ma, X. R. Liu, M. X. Ma, Study on Diffusion and Secondary Damage of Aerosol Fire Extinguishing Agent Based on Potassium Salts, Fire. Sci. Technol. 29 (2010) 60-63.

10. A. P. Denisyuk, D. L. Rusin, N. D.Long, Mechanism of combustion of fire-extinguishing propellants based on potassium nitrate, Dokl. Phys. Chem. 414 (2007) 99-102, doi: http:// dx.doi.org/10.1134/S0012501607050016.

11. J. L. Zhu, R. M. Pan, W. F. Zheng, Effect of combustible agent on combustion temperature of fire extinguishing agent, Fire. Sci. Technol. 33 (2014) 195-197.

\title{
SAŽETAK
}

\author{
Učinkovitost sredstva za gašenje požara vrućim aerosolom u gašenju \\ različito smještenog benzinskog plamena

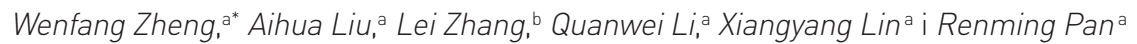

Sredstva za gašenje požara vrućim aerosolom moguća su zamjena za halone. Smještaj požara utječe na ponašanje, oblik i intenzitet vatre što djeluje na učinkovitost sredstva za gašenje. U ovome je radu sredstvom za gašenje požara vrućim aerosolom gašen benzinski plamen smješten na otvorenom prostoru, djelomično otvorenom i u zatvorenom prostoru. Prema rezultatima sredstvo za gašenje požara vrućim aerosolom učinkovitije je u zatvorenom nego na djelomično ili potpuno otvorenom prostoru. Plamen je najbrže ugašen kada je bio smješten u kutu, više vremena bilo je potrebno za gašenje plamena u središtu prostora, a najdulje je trajalo gašenje plamena uza zid u djelomično i potpuno otvorenom prostoru. Gašenje vatre također u određenom stupnju razbuktava plamen.

\footnotetext{
Ključne riječi

Sredstvo za gašenje požara vrućim aerosolom, lokalni požar, benzinski plamen, vrijeme gašenja požara, smještaj požara
}

\footnotetext{
${ }^{a}$ School of Chemical Engineering, Nanjing University of Science and Technology, Nanjing 210 094, Kina

b Shanghai Fire Research Institute of MPS, Shanghai 200 438, Kina
}

Stručni rad

Prispjelo 30. kolovoza 2016. Prihvaćeno 19. listopada 2016. 